\title{
Regenerative Proliferation in Organ Cultures of the Avian Cochlea: Identification of the Initial Progenitors and Determination of the Latency of the Proliferative Response
}

\author{
Mark E. Warchol ${ }^{1}$ and Jeffrey T. Corwin ${ }^{1,2}$ \\ ${ }^{1}$ Departments of Otolaryngology-Head and Neck Surgery and ${ }^{2 N e u r o s c i e n c e, ~ S c h o o l ~ o f ~ M e d i c i n e, ~ U n i v e r s i t y ~ o f ~ V i r g i n i a, ~}$ \\ Charlottesville, Virginia 22908
}

\begin{abstract}
Sensory hair cells in the cochleae of birds are regenerated after the death of preexisting hair cells caused by acoustic overstimulation or administration of ototoxic drugs. Regeneration involves renewed proliferation of cells in an epithelium that is otherwise mitotically quiescent. To determine the identity of the first cells that proliferate in response to the death of hair cells and to measure the latency of this proliferative response, we have studied hair-cell regeneration in organ culture. Cochleae from hatchling chicks were placed in culture, and hair cells were killed individually by a laser microbeam. The culture medium was then replaced with a medium that contained a labeled DNA precursor. The treated cochleae were incubated in the labeling media for different time periods before being fixed and
\end{abstract}

The sensory hair cells of the cochleae of mammals and birds are produced during embryonic development (Ruben, 1967; Katayama and Corwin, 1989). Loss of hair cells from the cochleae of postembryonic mammals is thought to be permanent and can result in irreversible deficits in hearing. Hair cell losses in the avian cochlea, however, are repaired after damage caused by acoustic trauma (Cotanche, 1987) or by the administration of ototoxic antibiotics (Cruz et al., 1987). This repair occurs through renewed proliferation of cells. Although cell proliferation in the chick cochlea normally terminates before hatching (Katayama and Corwin, 1989), the loss of hair cells from the mature cochlea triggers renewed cell proliferation, leading to the creation of replacement hair cells and supporting cells (Corwin and Cotanche, 1988; Ryals and Rubel, 1988).

The cellular mechanisms that trigger renewed proliferation in the avian cochlea are not yet understood, and the identity of the specific cell types that proliferate after cochlear damage has been the source of controversy. Several studies have concluded that cochlear supporting cells, like supporting cells in other hair cell epithelia (Corwin, 1986; Balak et al., 1990; Jones and Corwin, 1993), proliferate in response to the death of hair cells and that the progeny of those cell divisions can go on to

\footnotetext{
Received Jan. 18, 1996; revised May 31, 1996; accepted June 5, 1996.

This work was supported by the Neurobiological and Behavioral Development Training Grant, a National Research Service Award fellowship, a Deafness Research Foundation Grant, and National Institute on Deafness and Other Communication Disorders (NIDCD) Grant DC 02291 to M.E.W., and by grants from the NIDCD and the Lion's of Virginia Hearing Foundation to J.T.C. We thank Christine Laverack for skillful assistance in histological preparation.

Correspondence should be addressed to Mark E. Warchol, Department of Otolaryngology-HNS, Box 396, School of Medicine, University of Virginia, Charlottesville, VA 22908.

Copyright (C) 1996 Society for Neuroscience $\quad 0270-6474 / 96 / 165466-12 \$ 05.00 / 0$
}

processed for the visualization of proliferating cells. The first cells to initiate DNA replication in response to the death of hair cells were supporting cells within the cochlear sensory epithelium. All of the labeled supporting cells were located within 200 $\mu \mathrm{m}$ of the hair-cell lesions. These cells first entered S-phase $\sim 16 \mathrm{hr}$ after the death of hair cells. The results indicate that supporting cells are the precursors of regenerated hair cells and suggest that regenerative proliferation of supporting cells is triggered by signals that act locally within the damaged epithelium.

Key words: hair cell; hearing; ear; regeneration; cochlea; auditory system; precursor

differentiate as replacement hair cells and supporting cells (Corwin and Cotanche, 1988; Girod et al., 1989; Raphael, 1992; 1993; Hashino and Salvi, 1993; Stone and Cotanche, 1994). It has also been suggested, however, that hyaline cells, which reside outside of the inferior border of the sensory epithelium, may also divide and be the source of regenerated hair cells (Girod et al., 1989; Oesterle et al., 1992). These uncertainties have resulted in part from the fact that previous studies of hair-cell regeneration in the avian cochlea have relied on hair-cell lesions that were caused by acoustic overstimulation or by injection of ototoxic drugs. Considerable interspecimen variability is a common feature of both of these lesioning methods, making it impossible to determine accurately exactly how many hair cells had been killed, where the lesioned hair cells were located within the sensory epithelium of the cochlea, or the precise time of hair cell death. In the present study, chick cochleae were placed in organ culture and spatially patterned hair-cell lesions were made in their sensory epithelia using laser microsurgery. It was found that those lesions evoked proliferation among supporting cells that were located within $\sim 200 \mu \mathrm{m}$ of the lesions, but not in more distant supporting cells or among the hyaline cells located outside of the sensory epithelium. Hair cells died within 5 min after receiving a laser pulse, so the time required for supporting cells to make the transition from arrest at $G_{o}$ to the $S$-phase of the cell cycle in response to the death of hair cells could be determined with confidence. The first supporting cells to proliferate in response to the death of hair cells entered the S-phase of the cell cycle $\sim 16 \mathrm{hr}$ after the death of nearby hair cells. The findings suggest strongly that supporting cells near the sites of hair-cell lesions are the progenitors of regenerated auditory hair cells. 


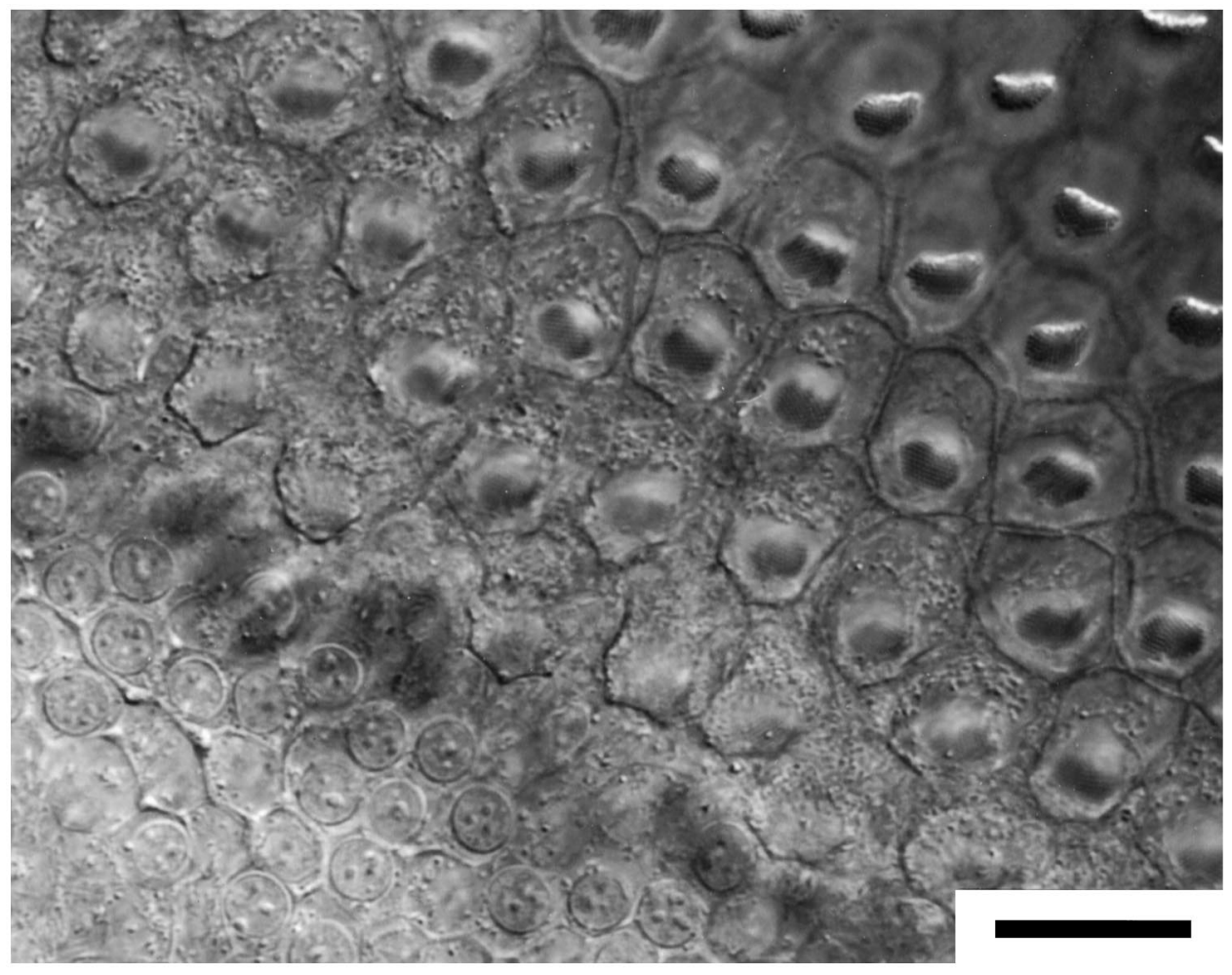

Figure 1. Photomicrograph showing a portion of the inferior region of a living chick cochlea after $24 \mathrm{hr}$ in culture in a Rose chamber. The specimen was viewed on an inverted microscope using a $100 \times$ objective lens. Hair cells and supporting cells in the cultured explants retain their normal morphology and can be visualized easily for laser ablation (see text). The nuclei of the hyaline cells are visible near the lower left corner. Scale bar, $20 \mu \mathrm{m}$.
Portions of these findings have been published previously in abstract form (Warchol et al., 1991; Warchol and Corwin, 1992).

\section{MATERIALS AND METHODS}

Preparation of cultures. Domestic chicks (White Leghorn strain; age, 7-14 $\mathrm{d}$ posthatch) were euthanized by carbon dioxide asphyxiation and decapitated. The skin covering the head was removed, and the lower jaw was dissected away. The heads were then immersed in chilled $70 \%$ ethanol for 5-10 min. The remaining dissection was carried out in a laminar flow culture hood to insure a pathogen-free environment. The middle ear space was exposed, and the bone overlying the proximal (basal) end of the cochlea was broken away. Cochleae were removed by grasping their very proximal tips with fine forceps. They were placed immediately in chilled Medium-199 (Life Technologies, Gaithersburg, MD) containing Hank's salts and $25 \mathrm{~mm}$ HEPES. The tegmentum vasculosum and lagena were dissected away so that the cultured specimens consisted of the cochlear sensory epithelium resting on the basilar membrane, which ran between the superior and the inferior fibrocartilagenous plates.

The dissected cochleae were placed on a small spatula and transferred to culture wells that contained $50 \mu \mathrm{l}$ of medium. Culture wells were constructed from 9-mm-diameter polyallomer rings cut from microcentrifuge tubes (Beckman 357448; Beckman, Fullerton, CA) and glued to $1 \frac{1}{2}$ coverglasses $(45 \times 50 \mathrm{~mm}$; Fisher $)$ with silicone type A medical adhesive (SILASTIC, model 981; Dow Corning, Corning, NY). The adhesive was cured for at least $16 \mathrm{hr}$ before sterilization in an autoclave. The inside surfaces of the wells were coated with Cell-Tak (Collaborative Research) that was diluted 1:5 with Medium-199. The Cell-Tak solution was left in the wells for $30 \mathrm{~min}$ and then rinsed out with sterile water.


Figure 2. Cells in living cultures of the chick cochlea can be individually lesioned using a laser microbeam. $A$, Cuticular plates of hair cells in the distal/inferior portion of a living chick cochlea after $24 \mathrm{hr}$ in culture. $B$, Photo of the same region 5 min after seven hair cells were killed individually using a pulsed laser microbeam. Arrows indicate the borders of the lesion. Note that the hair cells are completely missing from the cellular mosaic of the sensory epithelium, but that other cells appear unaffected. Scale bar, $20 \mu \mathrm{m}$. 


\section{Patterns of Hair Cell Ablation}

Figure 3. Patterns of hair-cell lesions used in the experiments. All hair-cell lesions were confined to the distalmost $1200 \mu \mathrm{m}$ of the cochlear sensory epithelium. $A$, One pattern of hair-cell lesion consisted of 100 hair cells that were arranged in a $10 \times 10$ hair cell square and located in the mid-inferior region of the sensory epithelium. The cells were killed individually with the laser microbeam (see text). $B$, The second type of lesion was composed of 250 hair cells, in a $5 \times 50$ hair cell array that originated near the distal tip of the epithelium. Experimental cochleae received one or the other of these lesions.

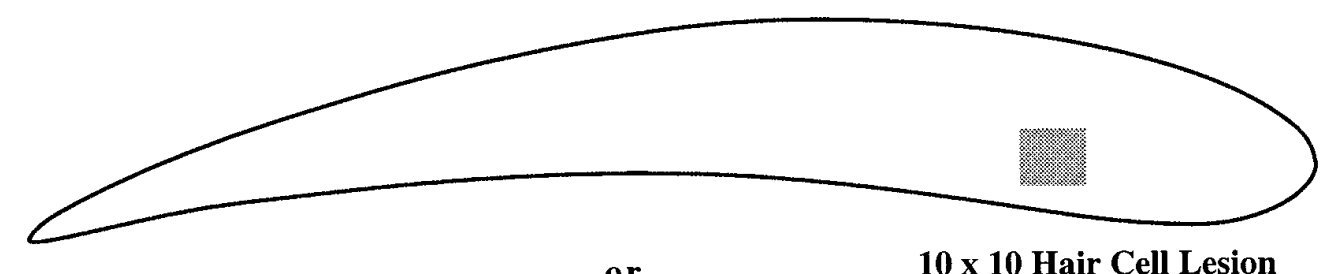

or

$10 \times 10$ Hair Cell Lesion

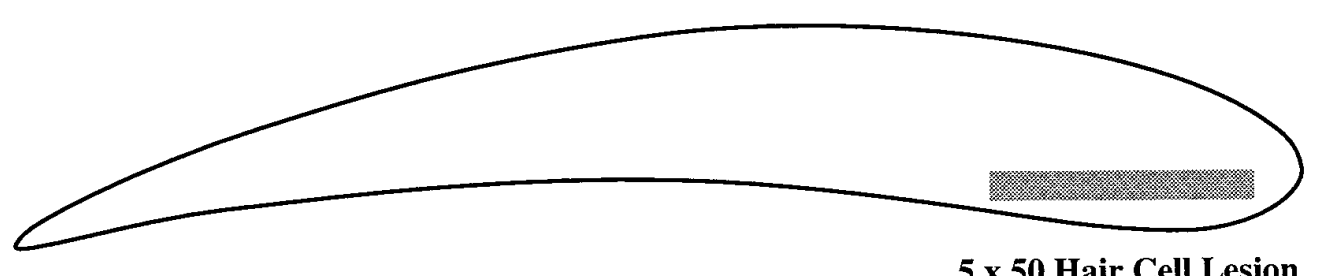

Each cochlea was maintained in $50 \mu \mathrm{l}$ of culture medium. The basal medium used in these experiments was Medium-199 with Earle's salts, 25 mM HEPES, $26 \mathrm{~mm}$ sodium bicarbonate, $0.69 \mathrm{~mm}$ L-glutamine, and $10-20 \%$ fetal bovine serum (Life Technologies). A single cochlea was oriented in the center of each well so that the ciliary bundles of its hair cells faced downward. Culture wells were then sealed in Rose chambers and incubated overnight at $37^{\circ} \mathrm{C}$ to allow time for the specimens to adhere to the Cell-Tak substrate. When placed in culture using these methods, the overall organization of the sensory epithelium of the cochlea was preserved for at least $3 \mathrm{~d}$.

Laser microbeam ablations. Hair-cell lesions in the cultured cochleae were created by laser microsurgery (Berns et al., 1981; Balak et al., 1990; Kelley et al., 1995). Rose chambers that contained cultured cochleae were placed on the stage of a modified inverted microscope (Zeiss Axiovert 35). A pulsed nitrogen laser (Laser Science, Newton, MA) (337 nm wavelength, $3 \mathrm{~ns}$ pulse width, $70 \mathrm{~kW}$ peak power) was mounted on an optical bench, and its beam was directed into the epi-illumination port of the Axiovert using two front-surface mirrors (Newport, Redwood City, CA). The path of the laser beam was aligned with the optical axis of the microscope, and the beam was focused through a quartz objective lens (Zeiss Ultrafluor, $100 \times, 1.25 \mathrm{NA}$ ). The focal point of the laser beam was made coincident with the specimen plane of the microscope by means of a focusing telescope that was mounted on the optical bench. The intensity of the laser beam was attenuated by inserting glass filters into the beam path.

A CCD video camera (Cohu) was mounted on the camera port of the Axiovert microscope for observation of the specimens during laser cell ablation. Clear images of hair cells and supporting cells could be obtained from most regions of the sensory epithelium (Fig. 1). When the $100 \times$ Ultrafluor objective was used, $\sim 50-100$ hair cells could be imaged simultaneously on the video screen. Hair cells were targeted individually for laser ablation by bringing their nuclei or cuticular plates to the point of focus of the laser microbeam. During and immediately after discharge of the laser, the focused laser beam appeared on the video monitor as a dark spot $\sim 1 \mu \mathrm{m}$ in diameter. When a single laser pulse was delivered to the nucleus or cuticular plate of a hair cell, an immediate disruption of the the cytoplasm was observed. Hair cells were usually killed after receiving one or two laser pulses and were extruded from the epithelium within 5 min (Fig. 2).

Two patterns of hair-cell lesions were produced in these experiments. One lesion pattern consisted of the individual ablation of 100 neighboring hair cells in a $10 \times 10$ array. The other pattern consisted of a lesion of 250 neighboring hair cells in a $5 \times 50$ array (Fig. 3). Each specimen received a single lesion in one of those patterns. Lesions were located in the inferior/central regions of the cochleae and confined to the distal 1200 $\mu \mathrm{m}$ of the length of the cochlea. The entire process of hair-cell lesioning was usually completed in $5-15 \mathrm{~min}$ in each cochlea. A heated stream of air kept the specimens at $\sim 37^{\circ} \mathrm{C}$ during lesioning.

Hair cells in 60 cochleae were lesioned as described. Immediately after the laser treatments, the culture medium was replaced with medium of identical formulation that also contained either $\left[{ }^{3} \mathrm{H}\right]$ thymidine or bromodeoxyuridine (BrdU) to label proliferating cells.
Autoradiographic labeling of proliferating cells. Thirty-four cochleae were incubated in medium that contained $0.8 \mu \mathrm{Ci} / \mathrm{ml}\left[{ }^{3} \mathrm{H}\right]$ methylthymidine (ICN; specific activity: $65-73 \mathrm{Ci} / \mathrm{mmol}$ ). The cultures were maintained at $37^{\circ} \mathrm{C}$ after the lesions for $4 \mathrm{hr}$ ( 3 specimens), $8 \mathrm{hr}(5$ specimens), $16 \mathrm{hr}$ (14 specimens), or $24 \mathrm{hr}$ (9 specimens). Three control

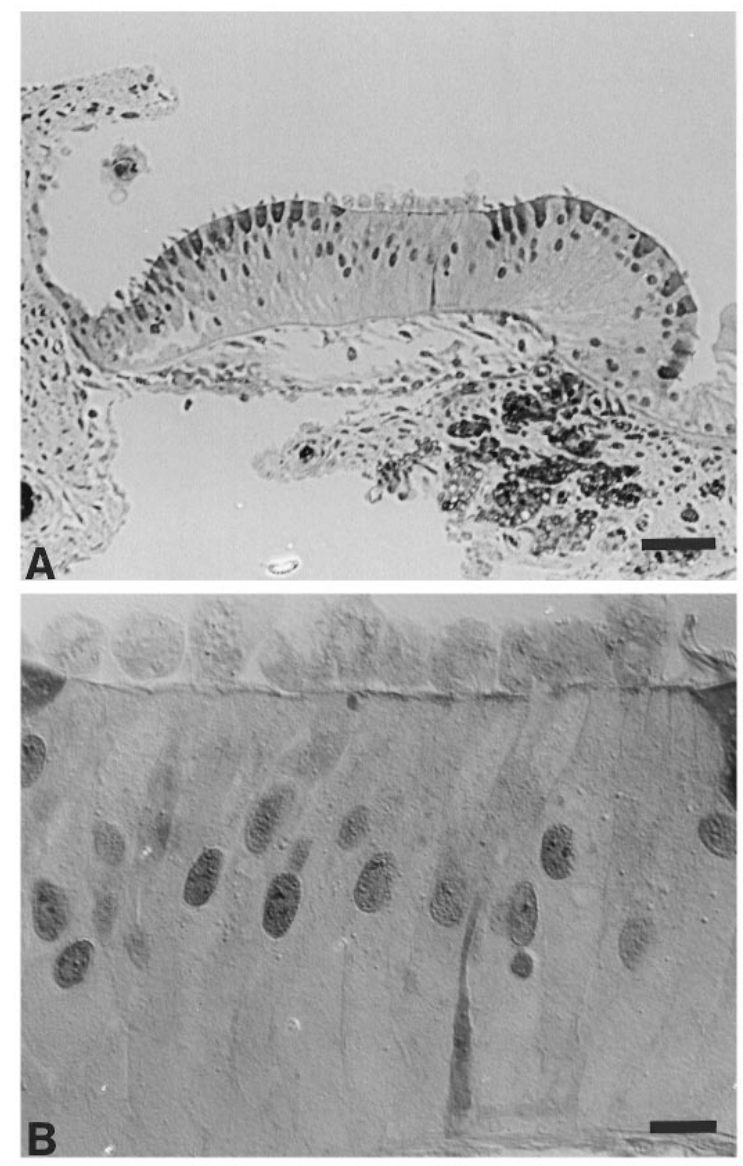

Figure 4. A, Autoradiograph showing a section from a chick cochlea $8 \mathrm{hr}$ after the laser ablation of hair cells. Hair cells are missing from a region near the center of the epithelium. $B$, Higher-power photomicrograph of the lesioned region in the same specimen. Normal-appearing supporting cells are present within the lesion. Note also the presence of extruded hair cells directly above the lumen of the lesioned portion of the sensory epithelium. Scale bars: $A, 50 \mu \mathrm{m} ; B, 10 \mu \mathrm{m}$. 

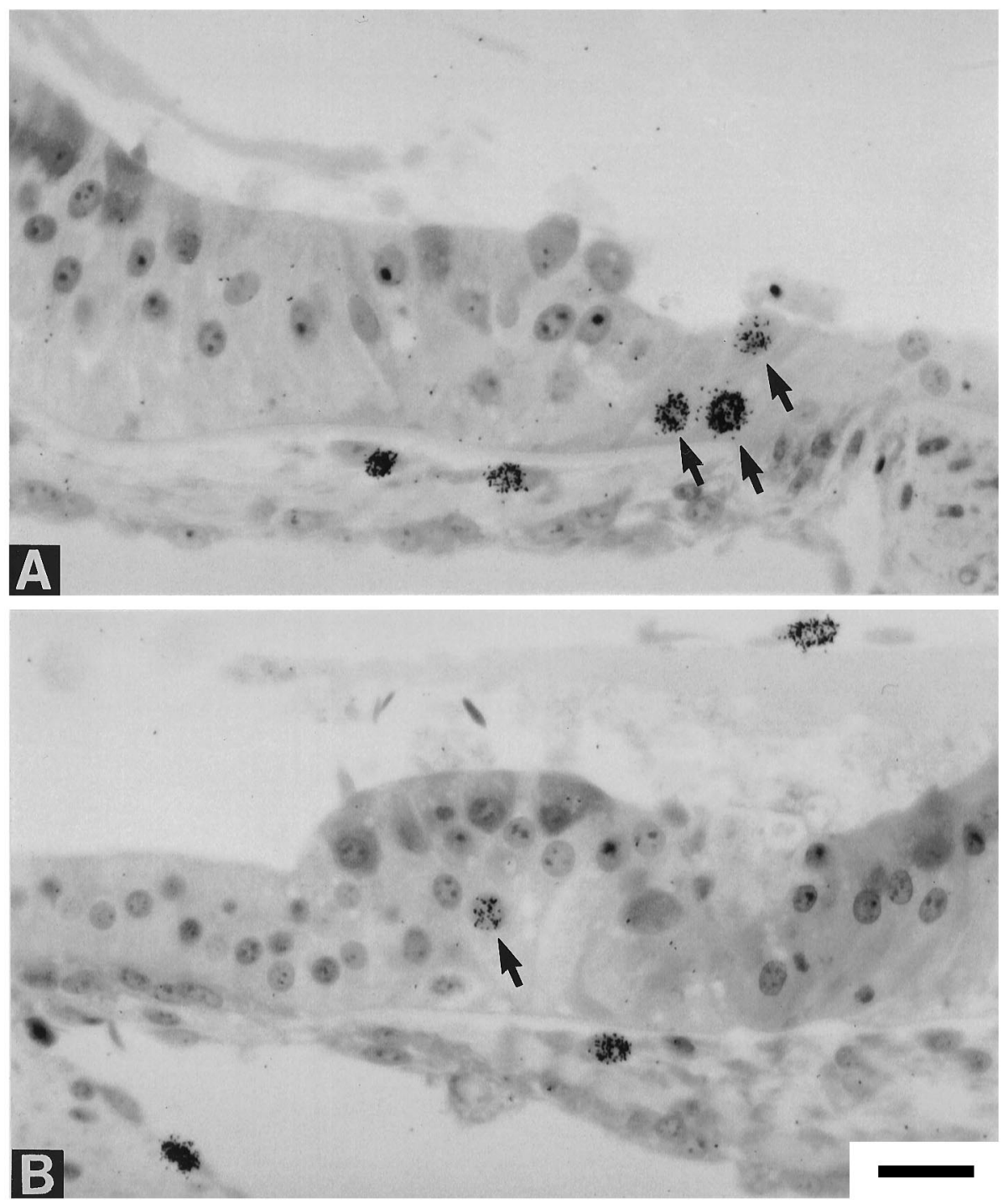

Figure 5. Autoradiographs of sections from chick cochleae that were incubated in medium that contained $\left[{ }^{3} \mathrm{H}\right]$ thymidine for $16 \mathrm{hr}$ after hair-cell lesions. Labeled supporting cells (arrows) were present within $(A)$ and directly adjacent to $(B)$ the lesioned areas. No lesion-related labeling of hyaline cells was present in these specimens. Scale bar, $20 \mu \mathrm{m}$. cochleae were not lesioned but were incubated for $24 \mathrm{hr}$ in medium that contained $\left[{ }^{3} \mathrm{H}\right]$ thymidine. After incubation with the tracer, the cochleae were fixed in $3 \%$ glutaraldehyde ( $\mathrm{pH} 7.4$ in $0.1 \mathrm{M}$ phosphate buffer), rinsed in $0.1 \mathrm{M}$ phosphate buffer, and postfixed in $1 \% \mathrm{OsO}_{4}$. Specimens were then dehydrated in a graded ethanol series and embedded in methacrylate (Historesin; Leica, Deerfield, IL). The distal-most 1000$1200 \mu \mathrm{m}$ of the cochlear sensory epithelia were sectioned serially at $3 \mu \mathrm{m}$ thickness. Every section was collected for autoradiographic processing. The sections were mounted on slides and coated with nuclear track emulsion (Kodak NTB-2). After 8-14 d of exposure in light-tight boxes, slides were developed in Kodak D-19 according to a published procedure (Corwin, 1985). They were stained with thionine or toluidine blue and coverslipped with Eukitt (Calibrated Instruments, Hawthorne, NY). Every cochlear section was examined microscopically for the presence of labeled cells.

BrdU immunohistochemical labeling of proliferating cells. In 29 experiments, the lesioned cochleae were incubated in medium that contained BrdU ( $3 \mu \mathrm{g} / \mathrm{ml}$ ) (Sigma, St. Louis, MO). The cultures were maintained in BrdU-containing medium at $37^{\circ} \mathrm{C}$ after the lesions for either $8 \mathrm{hr}(6$ specimens), $16 \mathrm{hr}$ (10 specimens), or $24 \mathrm{hr}$ (13 specimens). In addition, 10 control cochleae, which had been placed in culture using the methods described but had not been lesioned, were incubated for an additional 24 $\mathrm{hr}$ in medium that contained $3 \mu \mathrm{g} / \mathrm{ml} \mathrm{BrdU}$. After incubation in the tracer-containing medium, the cochleae were rinsed with fresh Medium199 and fixed in $4 \%$ paraformaldehyde (pH 7.4 in $0.1 \mathrm{~m}$ phosphate buffer) for $30 \mathrm{~min}$. They were then rinsed three times in PBS and treated in $90 \%$ methanol with $0.3 \% \mathrm{H}_{2} \mathrm{O}_{2}$ for $30 \mathrm{~min}$ to reduce endogenous peroxidase activity. The cochleae were placed in $2 \mathrm{~N} \mathrm{HCl}$ for $30 \mathrm{~min}$ to denature DNA and preblocked for $30 \mathrm{~min}$ in PBS that contained $0.5 \%$ bovine serum albumin and $2 \%$ normal goat serum. Specimens were incubated overnight in the primary antibody against BrdU [mouse IgG, Becton Dickinson 347580 (Becton Dickinson, San Jose, CA), diluted 1:50 in PBS with $1 \%$ Triton $\mathrm{X}-100$ and $2 \%$ normal goat serum] at $4{ }^{\circ} \mathrm{C}$. The specimens were rinsed $3 \times$ in PBS that also contained $0.5 \%$ bovine serum albumin, and an additional $3 \times$ in PBS alone, before incubation in $200 \mu \mathrm{l}$ of biotinylated horse anti-mouse IgG (diluted 1:200 in PBS) for 60-120 min, with slow agitation. After three rinses in PBS, the specimens were treated in a mixture of avidin and biotinylated-horseradish peroxidase for an additional $60-120$ min, with slow agitation. The secondary antibody and avidin-biotin reactions were carried out using a commercially available kit (PK4002, Vector Labs, Burlingame, CA). The cochleae were then rinsed $3 \times$ in PBS and reacted for 6-10 $\mathrm{min}$ in diaminobenzidine using a nickel intensification procedure (SK 4100 Peroxidase Substrate Kit, Vector Labs). They were mounted in PBS/ glycerol (1:9) and analyzed as whole mounts.

\section{RESULTS}

Two different patterns of hair-cell lesions were created in the cultured cochleae (Fig. 3). Approximately half of the specimens received each type of lesion. The two lesion patterns resulted in essentially the same spatial and temporal patterns of cell proliferation in the cochleae, so data obtained from both patterns of lesions are described together for each time point. 


\section{Identity of proliferating cells}

\section{Four and eight hours after hair-cell lesions}

Autoradiographic sections of the cultured cochleae that had been incubated for 4- and 8-hr periods after the lesioning of hair cells each contained a discrete region within the sensory epithelium where hair cells were absent. Supporting cells were present within the lesioned areas and seemed to be undamaged (Fig. 4). No labeled supporting cells were present in any of the cochleae that were incubated in tracer-containing medium for 4 or $8 \mathrm{hr}$ after the hair-cell lesions, but labeled cells were present in nonsensory tissues of these cochleae. Labeled cells were sometimes present in the interior of the basilar membrane and on its lower (scala tympani) surface, in the cartilagenous areas surrounding the sensory epithelium, among the Schwann cells that remained along the distal part of the auditory nerve, and in the areas near and within blood vessels. Labeled cells were more numerous after incubation with the tracer for $8 \mathrm{hr}$ than after incubation for $4 \mathrm{hr}$.

An additional six cochleae were incubated with BrdU for $8 \mathrm{hr}$ after lesioning. When viewed as whole mounts under sufficient magnification, the hair-cell lesions in those specimens could be visualized as regions of the sensory epithelium where hair cells were absent from the epithelial matrix. As with the specimens that were incubated with $\left[{ }^{3} \mathrm{H}\right]$ thymidine, none of these cochleae contained labeled supporting cells, although labeled cells were present in the nonsensory tissues. No labeled hyaline cells (see below) were observed in any of the specimens that were exposed to tracers for 4 or $8 \mathrm{hr}$.

\section{Sixteen hours after hair-cell lesions}

Labeled cells were present within the sensory epithelia of many of the cochleae that were incubated with DNA synthesis tracers for $16 \mathrm{hr}$ after the laser ablation of hair cells. In all cases, the labeled cells were unambiguously identified as supporting cells. Data were obtained from 14 lesioned cochleae incubated in medium that contained $\left[{ }^{3} \mathrm{H}\right]$ thymidine for $16 \mathrm{hr}$ after the hair-cell lesions. Seven of these cochleae received $10 \times 10$ hair-cell lesions; the other seven received $5 \times 50$ lesions (Fig. 3 ). Ten of the 14 lesioned cochleae contained labeled supporting cells, all within the lesion sites or in the undamaged areas of the epithelium immediately adjoining the lesions (Fig. 5). Labeled border-type supporting cells, defined as the inferior-most supporting cells within the sensory epithelium (Oesterle et al., 1992), were present in six cochleae $16 \mathrm{hr}$ after hair-cell lesions.

Ten additional cochleae were incubated in medium that contained BrdU for $16 \mathrm{hr}$ after the lesioning of hair cells. Eight of those cochleae received $5 \times 50$ hair-cell lesions; the remaining two received $10 \times 10$ lesions. Labeled supporting cells were present in six specimens that received $5 \times 50$ lesions (Fig. 6).

In addition to the labeling observed within the sensory epithelium, all specimens that were incubated with DNA synthesis tracers for $16 \mathrm{hr}$ or more contained labeled cells located immediately outside of the inferior boundary of the sensory epithelium (e.g., Fig. 6B). Cells in this region of the avian cochlea have been referred to as hyaline cells, because of their clear appearance after histological staining (Takasaka and Smith, 1971; Girod et al., 1989; Cotanche et al., 1992; Oesterle et al., 1992). Labeled hyaline cells were present along the length of the sensory epithelium both near and away from the sites of hair-cell lesions. Labeled hyaline cells were also present in all of the control cochleae that had not received hair-cell lesions. To assess the occurrence of labeling in the hyaline and supporting cells at locations near and away from the sites of hair-cell lesions, counts of labeled supporting and
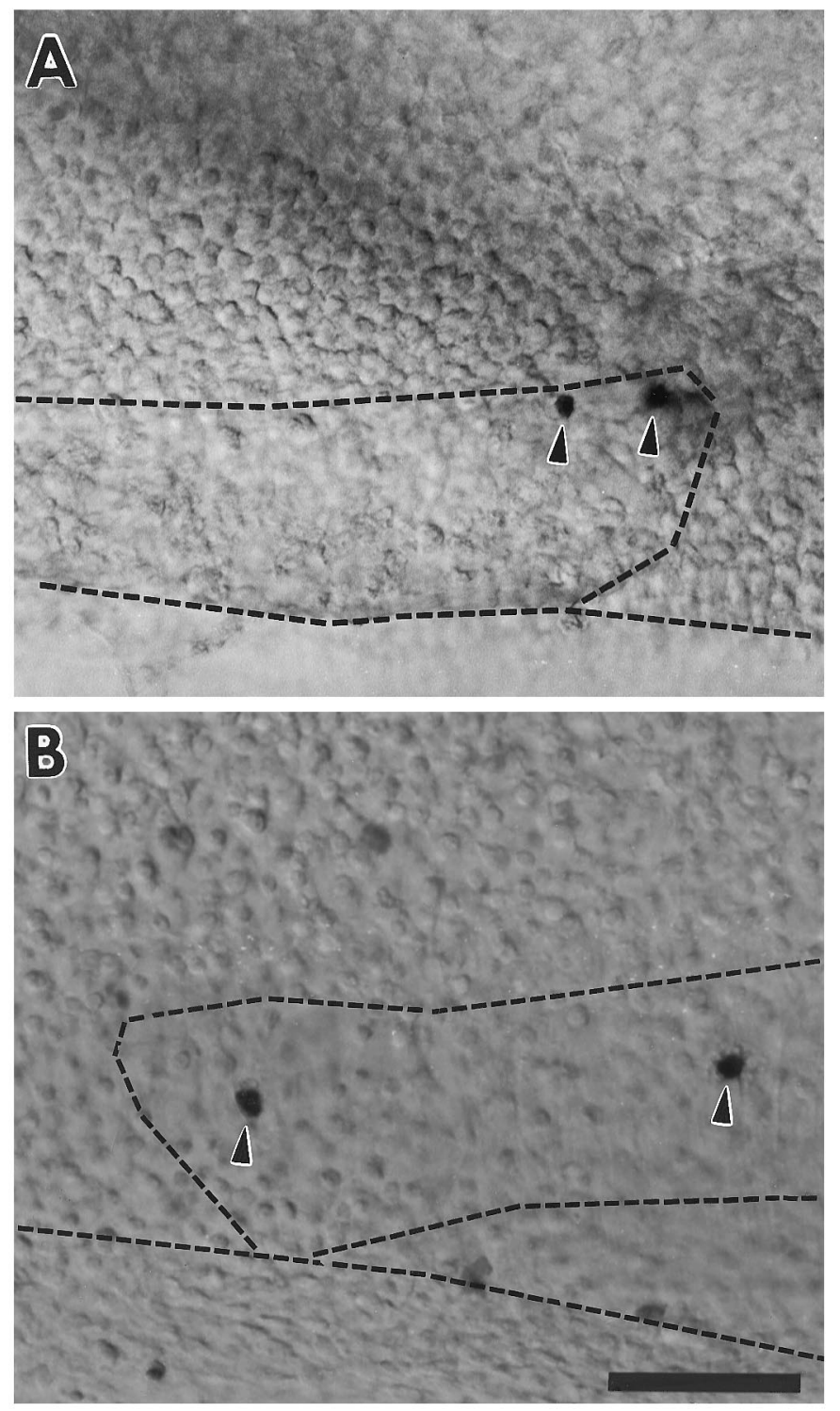

Figure 6. Labeled cells in whole mounts of cultured chick cochleae that were incubated in medium that contained the mitotic tracer BrdU for 16 $\mathrm{hr}$ after hair-cell lesions. The lower dashed lines in each photograph indicate the inferior borders of the sensory epithelia (the line separating border cells from hyaline cells). The other dashed lines indicate the borders of the hair-cell lesions, which were determined by microscopic examination of the whole-mount specimens. Labeled supporting cells were present in the lesioned regions of the sensory epithelia (arrows). Scale bar, $50 \mu \mathrm{m}$.

hyaline cells were made in 600- $\mu \mathrm{m}$-long segments of the cochleae that spanned the hair-cell lesions (Fig. 7). The counts showed that labeled supporting cells were concentrated near the hair-cell lesions. In contrast, the proliferation of hyaline cells showed no increase near the lesions. Labeled hyaline cells were common in the distal region of the cochleae, and usually were separated from the inferior boundary of the sensory epithelium by two to five unlabeled cells. No evidence for horizontal migration of hyaline cells toward or into the sensory epithelium was observed.

\section{Twenty-four hours after hair-cell lesions}

Nine cochleae were incubated in medium that contained $\left[{ }^{3} \mathrm{H}\right]$ thymidine for $24 \mathrm{hr}$ after the ablation of 100 hair cells in a $10 \times 10$ hair-cell array. Labeled supporting cells were present in six spec- 



Figure 7. Plots showing the distribution of labeled supporting cells and labeled hyaline cells along the length of the sensory epithelia of two cultured chick cochleae after incubation in $\left[{ }^{3} \mathrm{H}\right]$ thymidine for $16 \mathrm{hr}$ after the laser ablation of hair cells. Labeled cells in the autoradiographic sections were counted every $15 \mu \mathrm{m}$ over a total distance of $600 \mu \mathrm{m}$. In both plots, the $x$-axis denotes longitudinal distance along the cochlea, beginning $\sim 200 \mu \mathrm{m}$ from the distal tip and proceeding proximally. Labeled supporting cells were present only near the lesion sites. In contrast, labeled hyaline cells were commonly present outside the sensory region of the cochlea, but were not concentrated near the sites of the hair-cell lesions.

imens, both in the lesions and in apparently undamaged regions of the sensory epithelium within $200 \mu \mathrm{m}$ of the lesions (Fig. 8). Five of those cochleae also contained labeled border-type supporting cells. Labeled supporting cells were also present in 7 of 13 cochleae that were incubated in BrdU-containing medium for $24 \mathrm{hr}$ after lesioning (Fig. 9). Labeled hyaline cells were present in all specimens that were incubated in tracer-containing medium for 24 $\mathrm{hr}$ after the lesioning of hair cells, but hyaline cell proliferation did not seem to increase near the lesion sites (Fig. 10).

\section{The spatial distribution of proliferating supporting cells}

The spatial pattern of supporting cell proliferation was analyzed in whole-mount preparations of cochleae that received BrdU after hair-cell lesions. Camera lucida drawings were made of the sensory surfaces of five cochleae that survived for $16 \mathrm{hr}$ (Fig. 11) and five cochleae that survived for $24 \mathrm{hr}$ after $5 \times 50$ hair-cell lesions (Fig. 12). All lesions were located within $100 \mu \mathrm{m}$ of the inferior border of the sensory epithelium. The five cochleae that survived for $16 \mathrm{hr}$ postlesion contained 31 labeled supporting cells in total (two specimens each contained one labeled supporting cell, the remaining specimens contained 5, 7, and 17 labeled supporting cells, respectively). Fourteen labeled cells were within the lesions, whereas the remaining 17 labeled cells were in apparently undamaged regions of the sensory epithelia. Of those 17 labeled cells, 14 were located within $100 \mu \mathrm{m}$ of the lesions, and 3 were located within 100-180 $\mu \mathrm{m}$ of the borders of the hair-cell lesions. An additional lesioned cochlea was incubated in $\mathrm{BrdU}$ for $16 \mathrm{hr}$ postlesion and contained two labeled supporting cells that were located 150-200 $\mu \mathrm{m}$ from the lesion (data not shown). Labeled border-type supporting cells were present in three of the cochleae, one of which had received a lesion that extended to the inferior border of the sensory epithelium, as well as two that received lesions within $90 \mu \mathrm{m}$ of the inferior border.

A similar distribution was observed in five cochleae that survived for $24 \mathrm{hr}$ after the hair-cell lesions (Fig. 12). All hair-cell lesions in those specimens were located $<100 \mu \mathrm{m}$ from the inferior edge of the sensory epithelia, and two lesions seemed to contact the inferior edge. Thirty-four labeled supporting cells were present in total, with 23 located within the lesions. Five labeled cells were in apparently undamaged regions of the sensory epithelia within $25-100 \mu \mathrm{m}$ of the lesions, and two cells were in undamaged regions $100-110 \mu \mathrm{m}$ from the lesions. Four additional labeled cells were located near the distal tips of the cochleae. Labeled border-type supporting cells were present in the two specimens where the hair-cell lesions extended to the inferior edge of the sensory epithelium.

\section{Cell proliferation in unlesioned control cochleae}

Some proliferation of supporting cells and hyaline cells was observed in the unlesioned distal-most regions of cochleae that had been incubated in tracer-containing medium for 16 or $24 \mathrm{hr}$. This proliferation did not appear to have been evoked by the laserinduced hair-cell lesions, but was probably caused by trauma to this region of the cochleae that occurred during preparation for 


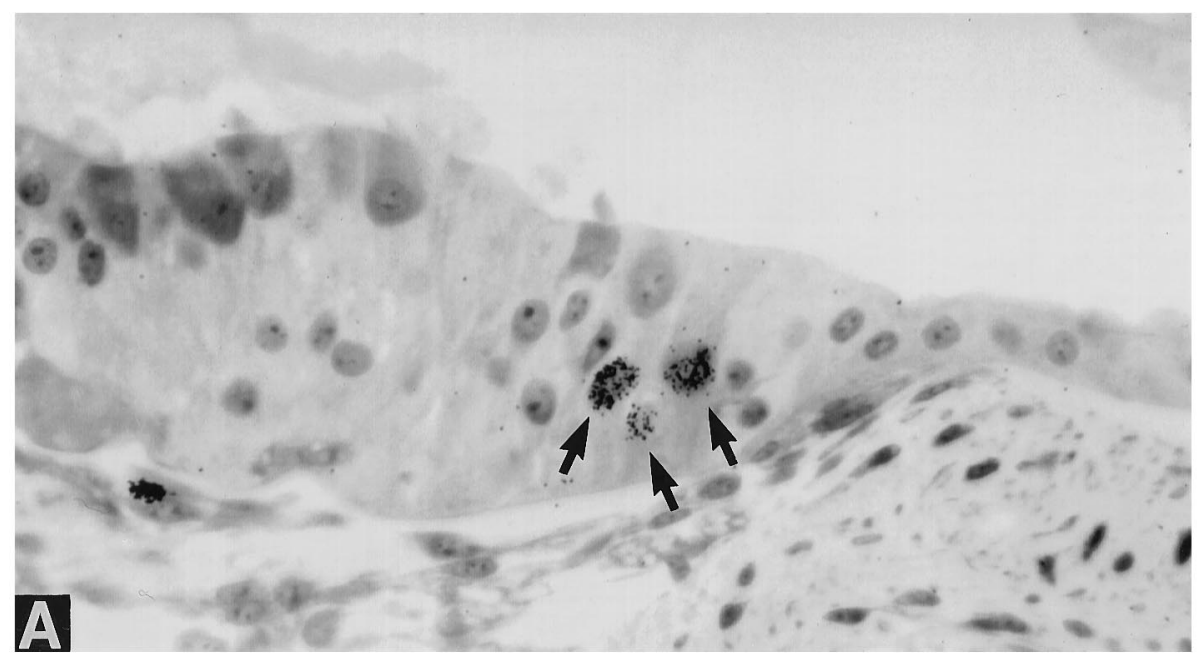

Figure 8. Autoradiographs of sections of chick cochleae that were incubated in medium that contained $\left[{ }^{3} \mathrm{H}\right]$ thymidine for $24 \mathrm{hr}$ after the lesioning of hair cells. Labeled supporting cells are indicated by arrows. The pattern of mitotic labeling that was present after $24 \mathrm{hr}$ incubations was similar to that present after the $16 \mathrm{hr}$ incubations. Labeled supporting cells were present within and near the hair-cell lesions. Scale bar, $20 \mu \mathrm{m}$.

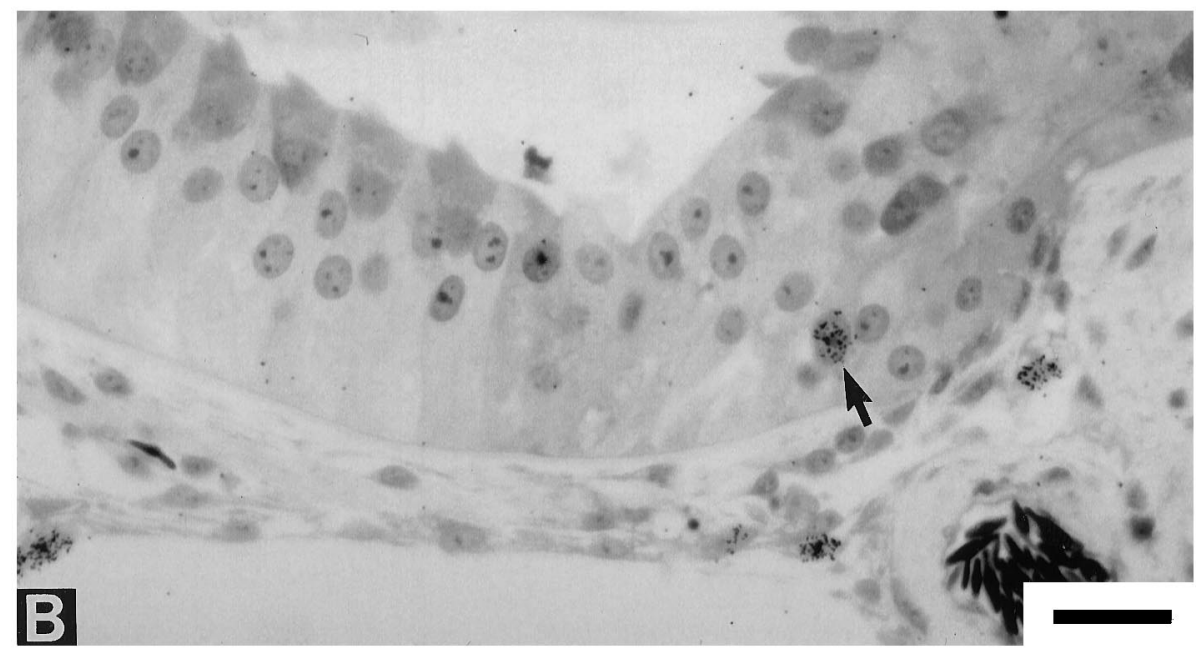

organ culture (i.e., during removal of the lagena). To quantify the extent and distribution of supporting cell proliferation in unlesioned specimens, 10 cochleae were prepared for culture as described but received no laser-induced hair-cell lesions. After overnight incubation, they received BrdU-containing medium and were incubated for an additional $24 \mathrm{hr}$. After processing to reveal BrdU-labeled cells, labeled supporting cells and hyaline cells were counted in 10 adjoining $100-\mu \mathrm{m}$-wide regions of epithelium, beginning at the distal tip (Fig. 13). The unlesioned cochleae contained $3.6 \pm 1.3$ (mean \pm SEM) labeled supporting cells in the distal-most $100 \mu \mathrm{m}$ length of sensory epithelium. The remaining sensory epithelium contained very few labeled supporting cells. In contrast, the number of labeled hyaline cells was approximately constant (approximately two to three labeled cells/100 $\mu \mathrm{m}$ ) throughout the distal-most $1000 \mu \mathrm{m}$ of the cochleae.

\section{DISCUSSION}

The results of the present study demonstrate that cochlear supporting cells proliferate in response to the death of nearby hair cells and that the latency for this response is $\sim 16 \mathrm{hr}$. The findings suggest that regenerative proliferation is triggered by a signal that acts locally within the epithelium.

\section{Identity of the first cells to proliferate after hair cell loss}

The identification of supporting cells as the first cells to proliferate in response to the death of hair cells is consistent with suggestions from several previous studies of regeneration in the cochlea (Corwin and Cotanche, 1988; Raphael, 1992; Hashino and Salvi, 1993; Stone and Cotanche, 1994, Bhave et al., 1995), the vestibular organs of chicks (Weisleder and Rubel, 1992, 1993), and the lateral line organs of amphibians (Corwin, 1986; Corwin et al., 1989; Balak et al., 1990; Jones, 1991; Jones and Corwin, 1993). In those studies, mitosis or mitotic labeling was observed in supporting cells after hair cells were killed in vivo either by sound damage or ototoxic antibiotics (chick cochlea and vestibule) or by compromise of the blood supply, tail-tip amputation, photoablation, or laser microsurgery (salamander lateral line). Studies of cell proliferation in organ cultures of the chick cochlea and vestibular organs (Oesterle et al., 1993) and of the utricles of adult mammals (Warchol et al., 1993; Lambert, 1994) have also demonstrated proliferation of supporting cells in response to the death of hair cells.

Supporting cells of the avian cochlea seem to form a more homogeneous morphological class than do their counterparts in the mammalian cochlea; however, a sub-type of supporting cell, termed "border cell," has been identified at the far inferior edge of the avian cochlear epithelium (Oesterle et al., 1992). Border cells have larger lumenal surfaces than do other supporting cells, and they receive synaptic contact from efferent cochlear neurons. In the present study, some of the supporting cells labeled after the hair-cell lesions were located at the inferior edge of the sensory epithelium and could be classified as border cells by the criteria of 



Figure 9. Photographs of whole mounts of cochleae that were cultured in medium that contained $\mathrm{BrdU}$ for $24 \mathrm{hr}$ after the lesioning of hair cells. The inferior borders of the sensory epithelia are oriented toward the bottom of both photographs and are indicated by the lower dashed lines. The upper dashed lines indicate the borders of the hair-cell lesions. Labeled supporting cells are present in the sensory epithelia of both specimens (arrows). Labeled cells are also present in the region outside of the inferior boundary of the sensory epithelia $(A)$. Scale bar, $50 \mu \mathrm{m}$.

Oesterle et al. (1992). Although it is possible that the progeny of proliferating border-type supporting cells may differentiate as hair cells in the far inferior regions of the avian cochlea, the present data do not suggest a unique role for border-type supporting cells in the process of hair-cell regeneration.

One study of hair-cell regeneration in the chick cochlea proposed that in addition to supporting cells, hyaline cells from outside the sensory epithelium can give rise to replacement hair cells and supporting cells (Girod et al., 1989). It was reported that the hyaline cells adjacent to the lesion were among the first cells to show increased proliferation after injury to hair cells, and it was suggested that the hyaline cells might serve as a latent stem-cell population in the avian cochlea. The present study found no evidence for an increase in hyaline cell proliferation in response to the death of hair cells. Labeled hyaline cells were present in both control and laser-treated cochleae but were not concentrated near the lesion sites. In addition, labeled hyaline cells were usually separated from the border of the sensory epithelium by several unlabeled hyaline cells. These results suggest that hyaline cells do not undergo regenerative proliferation in response to moderate hair-cell lesions. This conclusion is consistent with the results of recent in vivo studies of acoustic damage in the chick cochlea, which suggest a limited role for hyaline cells in the repair process, except in cases of severe damage that result in a complete loss of both hair cells and supporting cells (Cotanche et al., 1995). Significantly, in such cases of severe trauma, damaged epithelial supporting cells at sites of delamination are replaced by inwardly migrating hyaline cells, but hair-cell regeneration does not occur (Girod et al., 1995; Bunting et al., 1996)

\section{Latency of regenerative proliferation}

The laser-microbeam method of killing hair cells in the chick cochlea allowed precise timing of hair-cell death. Regenerative proliferation of supporting cells began $\sim 16 \mathrm{hr}$ after the death of hair cells. Supporting cells in the undamaged chick cochlea either do not proliferate or do so at an extremely low rate (Corwin and Cotanche, 1988; Oesterle and Rubel, 1993). Thus, the vast majority of supporting cells in undamaged cochleae are likely to be arrested in the $G_{0}$ phase of the cell cycle. The results of the present study indicate that the minimum time required for supporting cells to pass from $G_{o}$ into $S$ phase in response to the death of hair cells is $\sim 16 \mathrm{hr}$. That latency is comparable to the period required for cultured mammalian fibroblasts to make the transition from $G_{o}$ to $S$ phase after the end of serum arrest (Brooks, 1976). It is also in general agreement with in vivo estimates of the latency of regeneration in the avian cochlea. Although it is difficult in noise-damage studies to estimate precisely the time when hair cells may have died, hair cells begin to extrude from the sensory epithelium of the chick cochlea $\sim 12 \mathrm{hr}$ after the onset of acoustic overstimulation (Cotanche and Dopyera, 1990). Labeled supporting cells are observed in the chick cochlea 18-33 hr after the onset of acoustic overstimulation, and estimates of the latency of regenerative proliferation of supporting cells in the chick cochlea in vivo have ranged from 12 to 24 hr (Girod et al., 1989; Raphael, 1992; Hashino and Salvi, 1993; Stone and Cotanche, 1994).

\section{Proliferation in unlesioned cochleae}

A low level of supporting cell proliferation was also observed in cultured cochleae that did not receive hair-cell lesions (Fig. 13). This proliferation was confined almost entirely to the distal-most $100 \mu \mathrm{m}$ of the sensory epithelium and probably resulted from damage that occurred during removal of the lagena. In addition, proliferating hyaline cells were present along the entire length of the sensory epithelia of both lesioned and unlesioned specimens. Proliferation of hyaline cells also could have been caused by damage during dissection, but a low level of ongoing hyaline cell proliferation has been reported in the undamaged avian cochlea in vivo (Oesterle and Rubel, 1993).

\section{Pattern of regenerative proliferation}

In the present study, the death of hair cells resulted in the proliferation of supporting cells both within the damaged regions of the sensory epithelia and in apparently undamaged regions within $200 \mu \mathrm{m}$ of the lesions. Of the 65 labeled supporting cells in the whole-mount specimens, 37 labeled cells were located within the lesioned areas, 19 were located in undamaged regions within $100 \mu \mathrm{m}$ of the hair-cell lesions, and another 5 were $100-180 \mu \mathrm{m}$ 

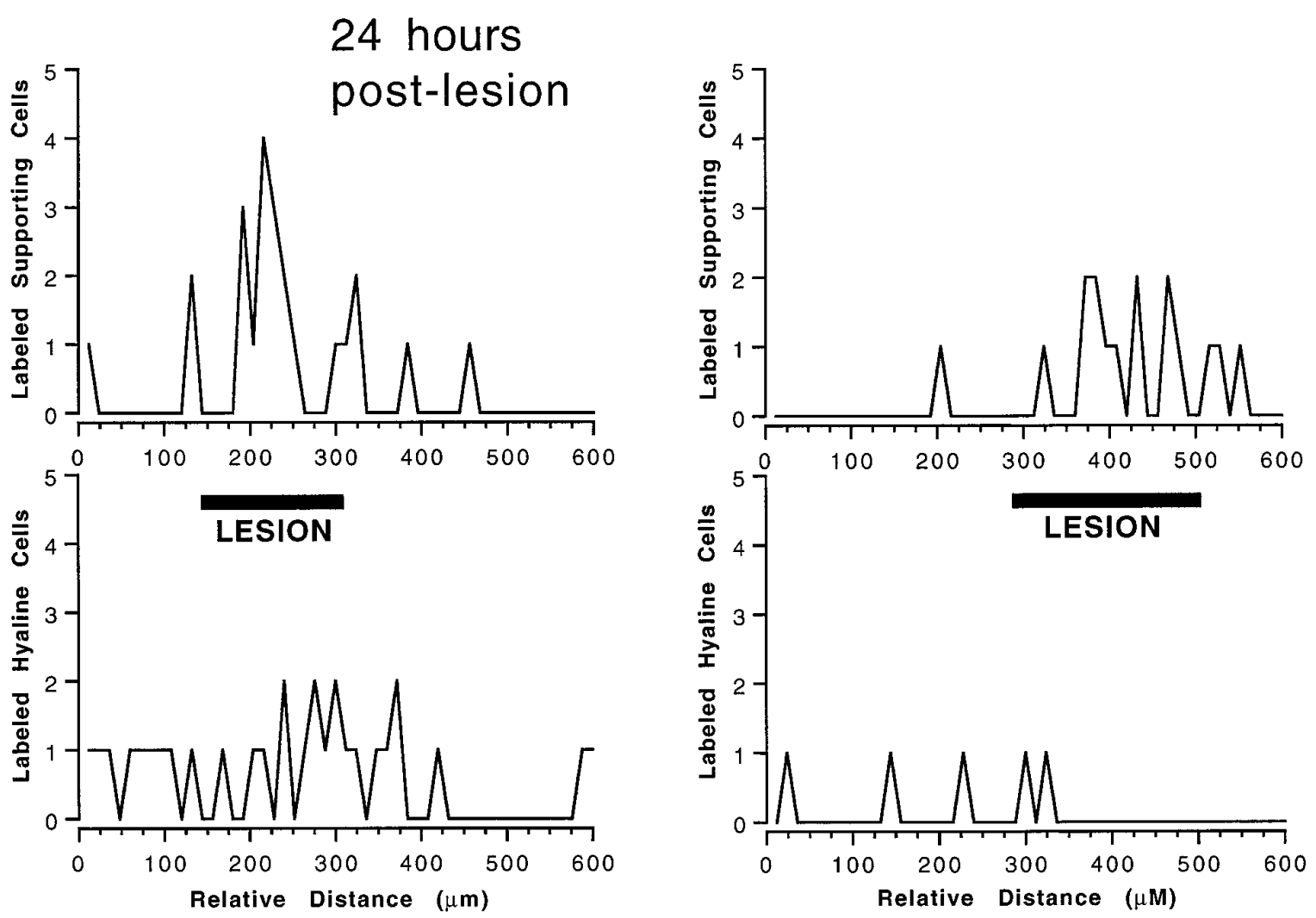

Figure 10. Plots showing the distribution of labeled supporting cells and labeled hyaline cells along the length of the sensory epithelia in two cultured chick cochleae after incubation in $\left[{ }^{3} \mathrm{H}\right]$ thymidine for $24 \mathrm{hr}$ after the laser ablation of hair cells. Labeled cells in autoradiographic sections were counted every $15 \mu \mathrm{m}$ over a total distance of $600 \mu \mathrm{m}$. In both plots, the $x$-axis denotes longitudinal distance along the cochleae, beginning $\sim 200 \mu \mathrm{m}$ from the distal tip and proceeding proximally. The general patterns of cell labeling were similar to those observed after 16 hr incubations (Fig. 8), although labeled cells were more numerous. Labeled supporting cells were concentrated near the lesion sites, whereas labeled hyaline cells were distributed along the entire inferior edge.

from the lesions. These results strongly suggest that regenerative proliferation in the cochlea is regulated by local cues. The cellular signals that trigger the proliferation of quiescent supporting cells are not known, but a number of hypothetical triggering mechanisms have been cataloged (Corwin and Warchol, 1991; Corwin et al., 1991). One hypothesis suggests that the proliferation of supporting cells may be inhibited via direct contacts with hair cells, so that the loss of hair cells could release adjacent supporting cells from inhibition, thereby allowing proliferation. Proliferation could continue until new hair cells had differentiated and reformed inhibitory contacts with surrounding supporting cells. Such a model would predict that the only cells to proliferate in response to the death of hair cells would be the supporting cells that had been in direct contact with the lesioned hair cells. The results of the present study are not in strict conformance with this model and suggest that contact-mediated inhibition cannot be the sole regulator of cell proliferation in the chick cochlea. After laser lesioning of hair cells, proliferating supporting cells were most often located within the regions where hair cells had been killed, as would have been predicted by the model. A lesser number of labeled supporting cells, however, were also present at locations that were near, but not within, the hair-cell lesions. These observations suggest a trigger for regenerative proliferation of supporting cells that can act over distances that are greater than those that could be mediated through direct contact between an injured hair cell and its immediately surrounding supporting cells. Evidence for hair-cell production away from the sites of hair-cell lesions in vivo has also been reported under conditions of acoustic overstimulation, where it is difficult to determine precisely the boundaries of the hair-cell lesions (Raphael, 1993).

How might a trigger for supporting cell proliferation be conveyed over short distances? The loss of hair cells may result in the release of mitogenic growth factors into the extracellular environment. The mitogens might then bind to receptors on supporting cells in the vicinity of the hair-cell lesions and trigger proliferation among those cells. Such diffusible growth factors could be released from dying hair cells or from adjacent supporting cells. Also, the loss of hair cells from the epithelial matrix of the inner ear will cause a redistribution of mechanical forces among the cells that remain in the epithelium, and it is conceivable that such changes in mechanical stress and/or cell shape could trigger the synthesis of mitogens (cf. Resnick et al., 1993). Several studies have suggested that mitogens are present in damaged hair cell epithelia (Xu and Corwin, 1993; Tsue et al., 1994).

Mitogenic growth factors might also be secreted by macrophages. Activated macrophages have been shown to produce numerous identified mitogens, which may trigger cell proliferation during epidermal wound healing (Rappolee and Werb, 1992). Macrophages also appear to be involved in the initiation of regenerative proliferation of supporting cells in lateral line neuromasts of axolotl salamanders (Jones, 1991; Jones and Corwin, 1993). After the lesioning of hair cells in those organs, macrophages were attracted to the lesioned epithelia and extended processes into the neuromasts that contacted and occasionally 

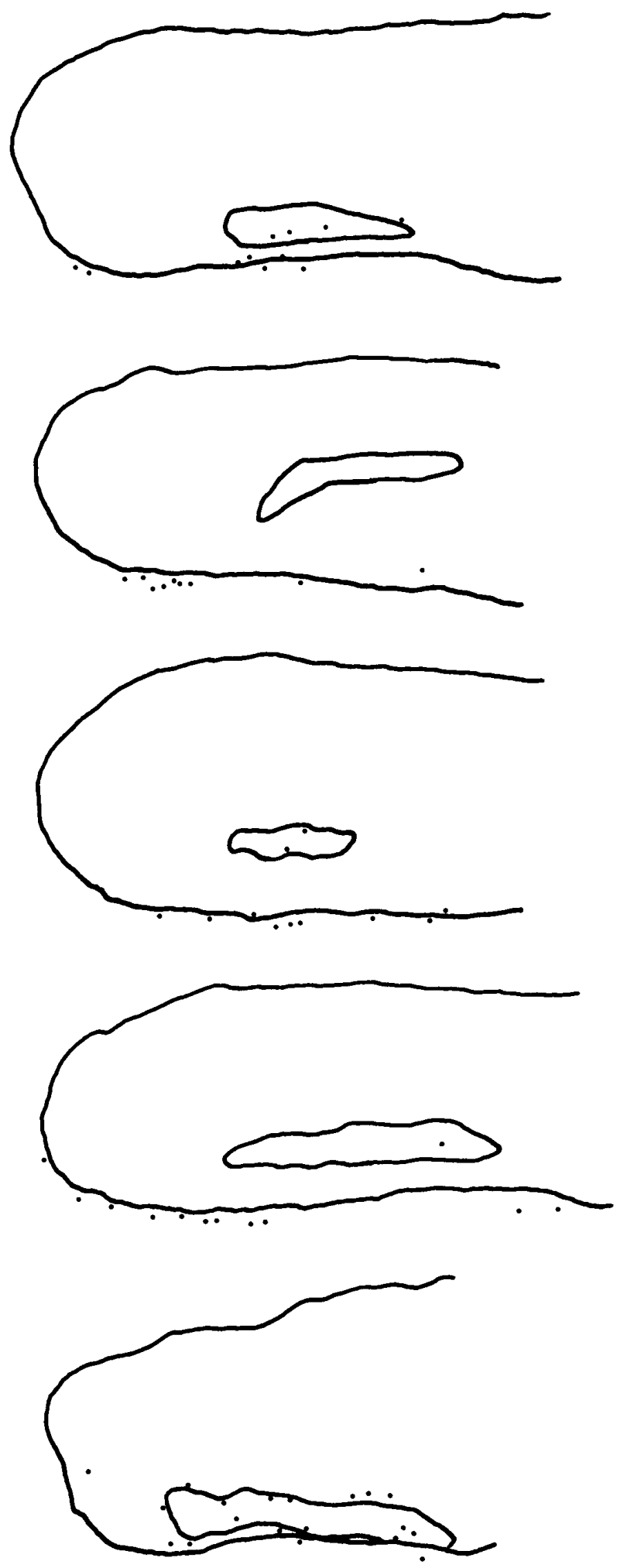

Figure 11. Camera lucida drawings of whole mounts of cultured cochleae that were incubated in medium that contained BrdU for $16 \mathrm{hr}$ after the lesioning of hair cells. In all cases, the cochleae are drawn with their inferior borders oriented downward. The outlines of the lesioned areas within the sensory epithelia are also indicated. Labeled supporting cells were present either within or near the hair-cell lesions. Labeled hyaline cells (see text) were also present in these specimens, but were not concentrated near the lesioned areas. Scale bar, $100 \mu \mathrm{m}$.
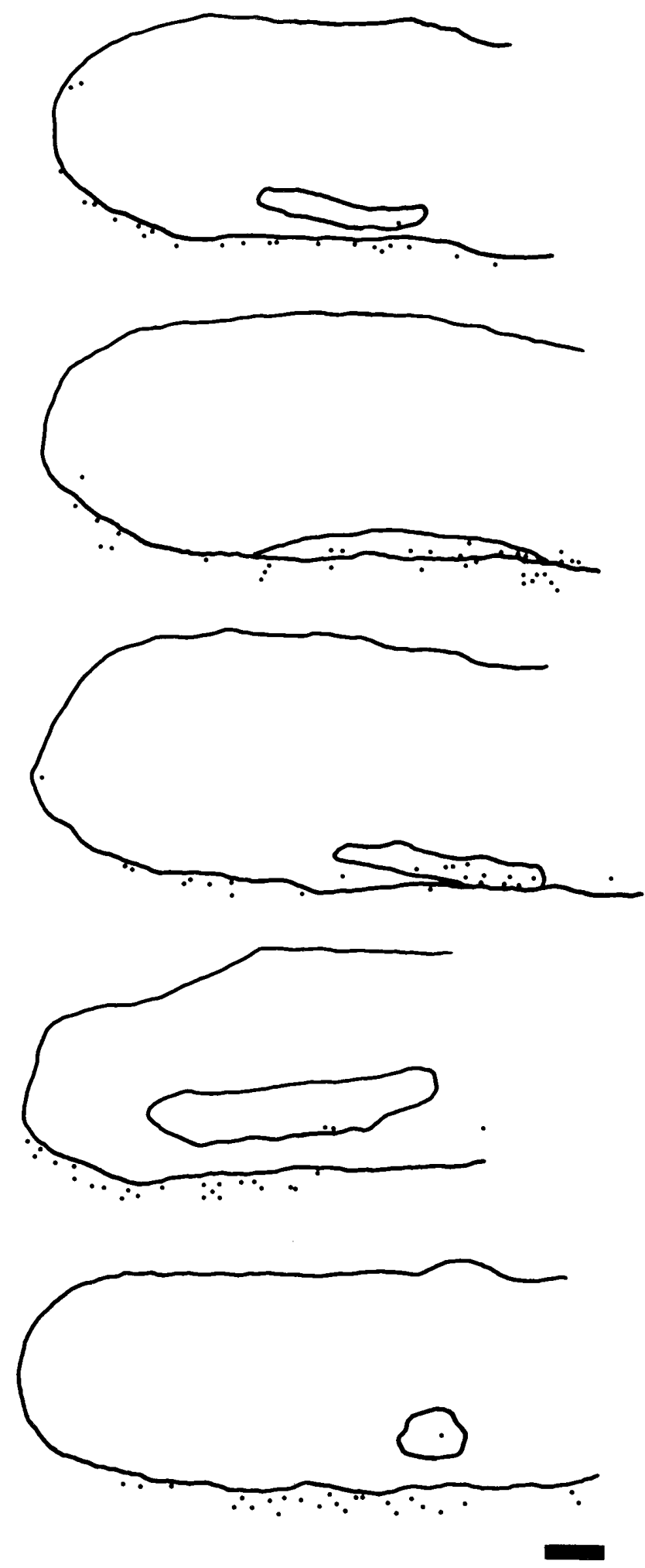

Figure 12. Camera lucida drawings of whole mounts of cochleae that were cultured in media that contained BrdU for $24 \mathrm{hr}$ after the lesioning of hair cells. The cochleae are oriented with their inferior borders downward, and the boundaries of the hair cells lesions are traced within the outlines of the sensory epithelia. The patterns of mitotic labeling after 24 $\mathrm{hr}$ incubations were similar to those present after $16 \mathrm{hr}$ incubations (Fig. 11). Labeled supporting cells were present within the lesions and at short distances from the lesions. Although labeled hyaline cells were present in all specimens, they were not concentrated near the lesion sites. Scale bar, $100 \mu \mathrm{m}$. 


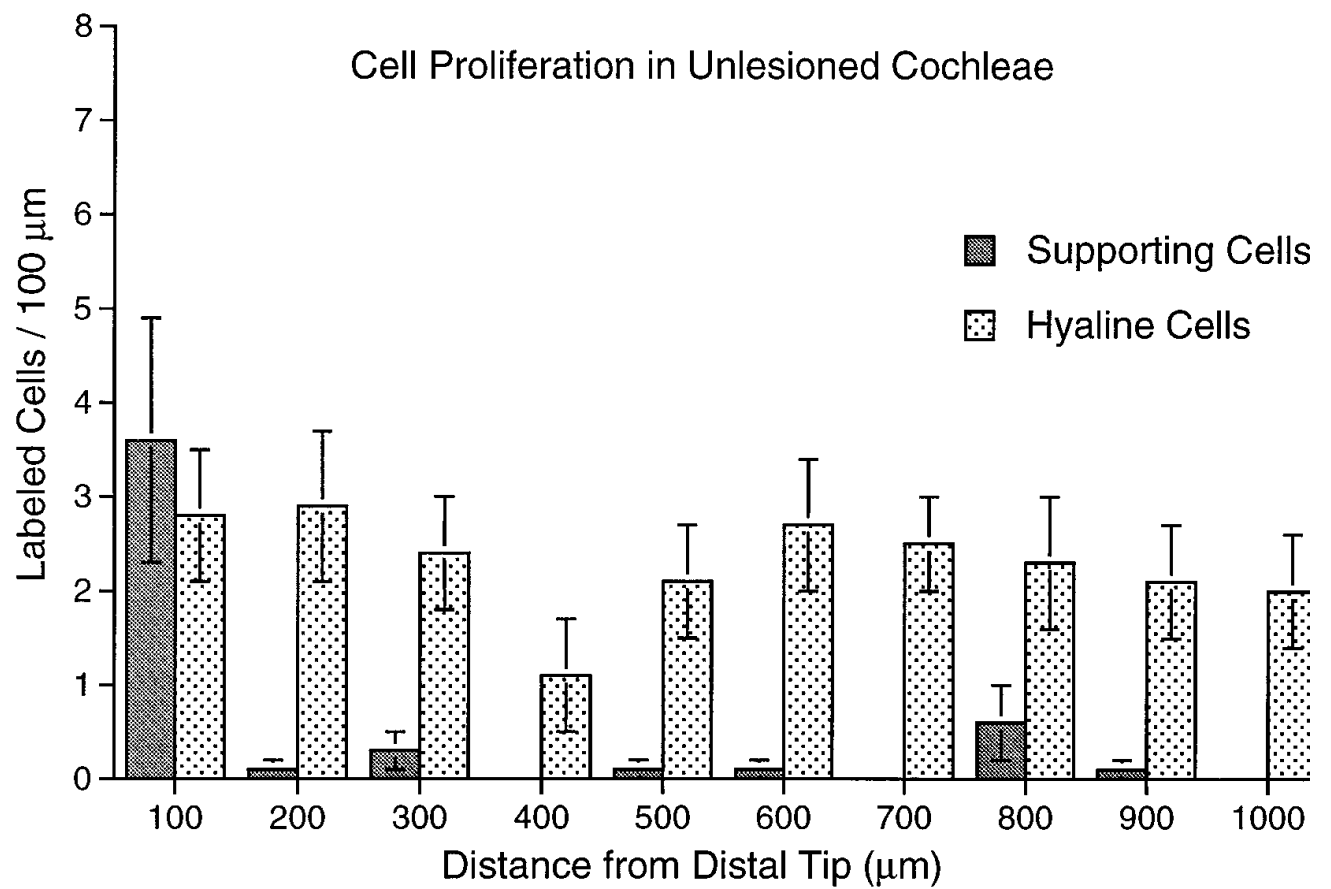

Figure 13. Plot showing the numbers and distribution of BrdU-labeled supporting cells and hyaline cells in 10 unlesioned cochleae. Cochlear cultures were prepared as described in the text but did not receive hair-cell lesions. The mitotic tracer BrdU was added to the medium for the final $24 \mathrm{hr}$ of culture. After fixation and histochemical processing, counts of BrdU-labeled supporting cells and hyaline cells were made from 10 adjoining $100 \mu \mathrm{m}$ regions of the cochleae, beginning at the distal tip and extending $1000 \mu \mathrm{m}$ toward the proximal end. Proliferating supporting cells were rare in unlesioned cochleae, except near the distal tip. In contrast, the numbers of proliferating hyaline cells were approximately uniform along the length of the unlesioned specimens. Mean \pm SEM. phagocytized supporting cells. Similar behavior of macrophages has been observed near the sites of hair-cell lesions in organ cultures of the chick cochlea (Warchol, 1995).

\section{REFERENCES}

Balak KJ, Corwin JT, Jones JE (1990) Regenerated hair cells can originate from supporting cell progeny: evidence from phototoxicity and laser ablation experiments in the lateral line system. J Neurosci 10:2505-2512.

Berns MW, Aist J, Edwards J, Strahs K, Girton J, McNeill P, Rattner JB, Kitzes M, Hammer-Wilson M, Liaw L-H, Siemens A, Koonce M, Peterson S, Brenner S, Burt J, Walter R, Bryant PJ, van Dyk D, Coulombe J, Cahill T, Berns GS (1981) Laser microsurgery in cell and developmental biology. Science 213:505-513.

Bhave SA, Stone JS, Rubel EW, Coltrera MD (1995) Cell cycle progression in gentamicin-damaged avian cochleas. J Neurosci 15:4618-4628.

Brooks RF (1976) Regulation of the fibroblast cell cycle by serum. Nature 260:248-250.

Bunting EC, Cotanche DA, Girod DA (1996) The role of hyaline cell migration in cochlear hair cell regeneration in chick basilar papilla following severe noise damage. Assoc Res Otolaryngol Abstr 19:15.

Corwin JT (1985) Perpetual production of hair cells and maturational changes in hair cell ultrastructure accompany postembryonic growth in an amphibian ear. Proc Natl Acad Sci USA 82:3911-3915.

Corwin JT (1986) Regeneration and self-repair in hair cell epithelia: experimental evaluation of capacities and limitations. In: The biology of change in otolaryngology. (Ruben RJ, Van De Water TR, Rubel EW, eds), pp 291-304. New York: Elsevier.

Corwin JT, Cotanche DA (1988) Regeneration of sensory hair cells after acoustic trauma. Science 240:1772-1774.

Corwin JT, Warchol ME (1991) Auditory hair cells: structure, function, development, and regeneration. Annu Rev Neurosci 14:301-333.

Corwin JT, Balak KJ, Borden PC (1989) Cellular events underlying the regenerative replacement of lateral line sensory epithelia in amphibians. In: The mechanosensory lateral line: neurobiology and evolution. (Combs S, Gorner P, Munz H, eds), pp 161-183. New York: Springer.

Corwin JT, Jones JE, Katayama A, Kelley MW, Warchol ME (1991) Hair cell regeneration: the identities of progenitor cells potential triggers and instructive cues. In: Regeneration of vertebrate sensory cells. (Bock GR, Whelan J, eds), pp 101-130. Ciba Foundation Symposium 160. New York: Wiley.

Cotanche DA (1987) Regeneration of hair cell stereociliary bundles in the chick cochlea following severe acoustic trauma. Hear Res 30:181-196.
Cotanche DA, Dopyera CEJ (1990) Hair cell and supporting cell response to acoustic trauma in the chick cochlea. Hear Res. 46:29-40.

Cotanche DA, Henson MM, Henson OW (1992) Contractile proteins in the hyaline cells of the chicken cochlea. J Comp Neurol 324:353-364.

Cotanche DA, Messana EP, Ofsie MS (1995) Migration of hyaline cells into the chick basilar papilla during severe noise damage. Hear Res 91:148-159.

Cruz RM, Lambert PR, Rubel EW (1987) Light microscopic evidence of hair cell regeneration after gentamicin toxicity in the chick cochlea. Arch Otolaryngol Head Neck Surg 113:1058-1062.

Girod DA, Duckert LG, Rubel EW (1989) Possible precursors of regenerated hair cells in the avian cochlea following acoustic trauma. Hear Res 42:175-194.

Girod DA, Ryal BM, Fankhauser CE, Westbrook EW (1995) Long term structural changes in the chick tectorial membrane following severe acoustic damage. Assoc Res Otolaryngol Abstr 18:787.

Hashino E, Salvi RJ (1993) Changing spatial patterns of DNA replication in the noise-damaged chick cochlea. J Cell Sci 105:23-31.

Jones JE (1991) Regeneration in the lateral line: identities of progenitor cells and the action of leukocytes. PhD thesis. University of Virginia.

Jones JE, Corwin JT (1993) Replacement of lateral line sensory organs during tail regeneration in salamanders: identification of progenitor cells and analysis of leukocyte activity. J Neurosci 13:1022-1034.

Katayama A, Corwin JT (1989) Cell production in the chick cochlea. J Comp Neurol 281:129-135.

Kelley MW, Talreja DR, Corwin JT (1995) Replacement of hair cells after laser microbeam irradiation in cultured organs of Corti from embryonic and neonatal mice. J Neurosci 15:3013-3026.

Lambert PR (1994) Inner ear hair cell regeneration in a mammal: identification of a triggering factor. Laryngoscope 104:701-718.

Oesterle EC, Rubel EW (1993) Postnatal production of supporting cells in the chick cochlea. Hear Res 66:213-224.

Oesterle EC, Cunningham DE, Rubel EW (1992) Ultrastructure of hyaline, border, and vacuole cells in chick inner ear. J Comp Neurol 318:64-82.

Oesterle EC, Tsue TT, Reh TA, Rubel EW (1993) Hair-cell regeneration in organ cultures of the postnatal chicken ear. Hear Res 70:85-108.

Raphael Y (1992) Evidence for supporting cell mitosis in response to acoustic trauma in the avian inner ear. J Neurocytol 21:663-671.

Raphael Y (1993) Reorganization of the chick basilar papilla after acoustic trauma. J Comp Neurol 330:521-532.

Rappolee DA, Werb Z (1992) Macrophage-derived growth factors. In: Macrophage biology and activation (Russell SW, Gordon S, eds), pp 87-140. New York: Springer.

Resnick N, Collins T, Atkinson W, Bonthron DT, Dewey CF, Gimbrone MA (1993) Platelet-derived growth factor B chain promoter contains a 
cis-acting fluid shear-stress-responsive element. Proc Natl Acad Sci USA 90:4591-4595.

Ruben RJ (1967) Development of the inner ear of the mouse: an radioautographic study of terminal mitosis. Acta Otolaryngol [Suppl] 220:1-44.

Ryals BM, Rubel EW (1988) Hair cell regeneration after acoustic trauma in adult Cotirnix quail. Science 240:1774-1776.

Stone JS, Cotanche DA (1994) Identification of the timing of S phase and the patterns of cell proliferation during hair cell regeneration in the chick cochlea. J Comp Neurol 341:50-67.

Takasaka T, Smith CA (1971) The structure and innervation of the pigeon's basilar papilla. J Ultrastruct Res 35:20-65.

Tsue TT, Oesterle EC, Rubel EW (1994) Diffusible factors regulate hair cell regeneration in the avian inner ear. Proc Natl Acad Sci USA 91:1584-1588.

Warchol ME (1995) Macrophages are recruited to hair cell lesions in the avian cochlea. Assoc Res Otolaryngol Abstr 18:331.
Warchol ME, Corwin JT (1992) Hair cell regeneration in vitro: determination of the latency and pattern of cell proliferation. Assoc Res Otolaryngol Abstr 15:315.

Warchol ME, Laverack C, Corwin JT (1991) Regenerative cell proliferation in organ cultures of the mature avian cochlea. Soc Neurosci Abstr 17:250.6.

Warchol ME, Lambert PR, Goldstein BJ, Forge A, Corwin JT (1993) Regenerative proliferation in inner ear sensory epithelia from adult guinea pigs and humans. Science 259:1619-1622.

Weisleder P, Rubel EW (1992) Hair cell regeneration in the avian vestibular epithelium. Exp Neurol 115:2-6.

Weisleder P, Rubel EW (1993) Hair cell regeneration after streptomycin toxicity in the avian vestibular epithelium. J Comp Neurol 331:97-110.

Xu X-M, Corwin JT (1993) A protein with TGF-a-like immunoreactivity is expressed in the cochlea and may be up-regulated during hair cell regeneration. Soc Neurosci Abstr 649.11. 